\title{
Assessing Accrual Accounting Implementation in Cianjur Regency: An
}

\section{Empirical Investigation}

\author{
Aditya Wira Dianto ${ }^{1}$, Khoirul Aswar ${ }^{2}$ \\ Universitas Pembangunan Nasional Veteran Jakarta, Jl. RS Fatmawati No.1 - Pondok Labu, Jakarta Selatan 12450
}

\begin{tabular}{l}
\hline ARTICLE INFO \\
\hline Article History \\
Received 04 February 2020; \\
Accepted 18 March 2020 \\
\hline JEL Classifications \\
I28, M15, M48
\end{tabular}

ABSTRACT

Purpose:

This research aimed to analyse the effect of top management support, training and communication on the implementation of accrual accounting.

Design/methodology/approach:

JEL Classifications

The hypotheses of the study were tested using the survey data from 63 working unit in Cianjur Regency. The instrument for content and construct validity and reliability was tested. Then, the hypotheses were tested using Structure Equation Modelling (SEM) by SmartPLS 3.0.

Finding:

This study found that top management support and training have significant relationship with implementation of accrual accounting. Meanwhile, communication has no significant relationship with implementation of accrual accounting.

Research limitations/implications:

This study contributes to provide input into the adoption of Government Regulation No. 71 of 2010 in order to apply the rule of accrual accounting to the fullest, and to minimize errors in financial reporting with the identification of possible obstacles faced in implementing accrual accounting. This study recommended that, more factors such as consultant support, education level and project management support are needed to complement and improve

Keywords:

Implementation of Accrual Accounting, Training, Top Management Support, Communication. financial reporting with implementation of accrual accounting.

Originality/value:

To the best of the researcher's knowledge, no study of Cianjur Regency has tested the impact of factor such as top management support, training and communication on implementation of accrual accounting.

\section{Introduction}

Reformation of public sector was started in 1980s. It occurred in developed countries as the answer of criticism because the public sector was considered inefficient, always loss, unproductive, poor innovation and creativity, and low quality. The reforms were as a result of changes by introducing the approach of reinventing government and the New Public Management (NPM) adopted by several countries, especially the Anglo-Saxon countries. The purpose of this NPM global phenomenon is to improve efficiency and effectiveness, increase responsibility and improve managerial accountability of public organizations (Aswar \& Saidin, 2018).

In Indonesia, the application of NPM began with reforms in the financial sector with the inception of three sets of laws, which were Law (UU) No. 17 of 2003 concerning State Finance and No. 1 of 2004 concerning the State Treasury, and Law No. 15 of 2004 concerning the Examination of Management and Responsibility of State Finances. The existence of the three sets of laws had marked the start of a new era in the management of state finances. Furthermore, from this phenomenon, PP No. 24 of 2005 concerning Government Accounting Standards (SAP) based on cash towards accruals accounting. In 2010, Indonesian government has issued Government Regulation (PP) No. 71 of 2010 concerning Accrual Based Accounting concerning Government Accounting Standard.

The supreme audit agency (BPK) of 542 LKPD in 2018 stated Unqualified opinion over 443 (83\%), qualified opinion of $86(16 \%)$, and disclaimer opinions of $13(2 \%)$. While compared to the achievements in 2017 , the quality of LKPD in 2018 had increased as indicated by an increase in unqualified opinion by $6 \%$ points, from $76 \%$ in 2017 to 
$82 \%$, in 2018. In 2017, 411 of 542 LKPD received unqualified opinion (76\%), while in 2018443 of 542 LKPD obtained unqualified opinion (82\%) (IHPS I in 2019).

Besides, as revealed in the Notes to the Financial Statements, the Government of Cianjur District/Regency presented Building Expenditures and Buildings of IDR 267.22 billion. From this value, there was a realization of IDR 4.95 billion accounted for as the procurement of facilities and infrastructure of the State Junior High School. However, it was used not in accordance with its accountability.

As the disclosure in Notes to the Financial Statements, The Cianjur District Government presented a Grant Expense of IDR 241.36 billion. Of this value, there was a realization of IDR 2.77 billion. It was accounted for as the procurement of facilities and infrastructure for Private Junior High Schools. However, it was used not in accordance with its accountability (BPK 2018). Based on the identification of the problems which have been found above, this research aims to examine and analyse whether the top management support, training, communication affect accrualbased accounting

Some previous studies on the implementation of accrual accounting. For example, Agyemang (2017), Cohen et al, (2007), Christiaens (2001) found that the obstacle of public sector in the application of accrual accounting in the transition period is related to the organizational and procedural factors. In line with research in Indonesia found that some obstacles on the accrual accounting implementation which is lack of human resources, motivation and incentive, information technology, effective communication and support from top management (Aswar \& Saidin, 2018; Harun \& Kamase, 2012; McLoad \& Harun, 2014; Harun et al, 2012).

In particular, this paper focuses on the factor influencing on the implementation of accrual accounting in Cianjur Regency. Furthermore, the aim of this study is to examines the relationship between top management support, training and communication on the implementation of accrual accounting in Cianjur Regency.

\section{Theoretical Perspective}

Based on Scott (2008), Institutional Theory is new institutional approach in studying organizational sociology. The theoretical source comes from cognitive theory, cultural theory, as well as phenomenology and ethnomethodology. There are 3 elements of analysis which build institutions even though some elements are dominant. However, these elements combine with each other. They come from different perspectives on the nature of social reality and social order in earlier sociological traditions. Furthermore, Scott (2008) explains the existence of 3 pillars in a new institutional perspective. First is regulative pillars. It works in the context of rules, monitoring and sanctions. This relates to the capacity to enforce rules, and provide rewards and penalties. This approach draws closer to enforcement through informal and formal mechanisms. Development will provide opportunities as well as limits to individuals who work through the pillars of repression and restrictions. Thus, individuals in this organization will be seen as a context which will maximize profits. Therefore, these institutions are often also referred to as regulatory institutions and rational choice institutions.

Second is normative pillars. In this view, norms produce evaluative perceptions and affirm responsibility in social life. This pillar includes values and norms. Norms are useful for guiding individuals what goals are to be achieved, and how to achieve them. Therefore, this section is often referred to as normative institutions and historical institutions. This is often referred to as the "original institutional" theory. Third is cultural-cognitive pillar. The core of this pillar is that humans behave is highly determined by how he interprets the meaning of the world and its environment.

\section{Hypothesis Development and Conceptual Scheme}

\subsection{The Effect of Top Management Support toward Accrual based Implementation}

The change of management in applying accrual accounting is highly needed because Top management support becomes an important factor in the implementation of accrual accounting in accordance with institutional theory which states that top management support has a very important role in achieving these goals. Aswar and Saidin (2018) found that there was a positive effect between top management support toward the implementation of accrualbased accounting. In line with previous research, it states that that there is a relation between top management support for the implementation of accrual-based accounting Rosyadi and Mulyani (2017). Besides, top management support has a positive effect on accrual-based implementation (Safitri, 2017; Nasution 2016; Kristiawati 2015; Putra \& Ariyanto, 2015). Based on the explanation above, this argument leads to the following hypothesis:

H1: Top management support has a positive effect on the implementation of accrual-based accounting

\subsection{The Effect of Training toward Accrual Based Implementation}

Training is an important part in implementing accrual accounting. This is in line with institutional theory which states that part of the training is professionalism to exert pressure on accrual accounting reform. Previous studies have found that training has a positive effect toward the implementation of accrual accounting (Aswar \& Saidin, 2018; Cavaluzzo \& Ittner, 2004, Jantong et al, 2018, Ridder \& Bruns, 2006). Based on the discussion above, this hypothesis is formulated as follow:

H2: Training has a positive effect toward the implementation of accrual accounting. 


\subsection{The Effect of Communication toward Accrual Based Implementation}

Good communication is a very important aspect for group effectiveness or any organization. Good communication in an organization will be able to work systematically to improve productivity, especially in applying the implementation of accrual accounting. Good communication will affect the implementation of accrual accounting. This is in accordance with institutional theory which states that the encouragement of communication will increase human communication between the organizational environment. Thus, the application of accrual accounting is getting better.

Several researches found a positive relationship between communication and the implementation of accrual accounting. This shows that the better communication carried out by the SKPD in socializing and applying government accounting standards, the higher level of application of accrual government accounting standards in the area (Safitri, 2017; Putra \& Ariyanto, 2015; Pratiwi et al, 2017). Based on the explanation above, this argument leads to the following hypothesis:

H3: Communication affects the implementation of accrual accounting.

Figure 1: Research framework

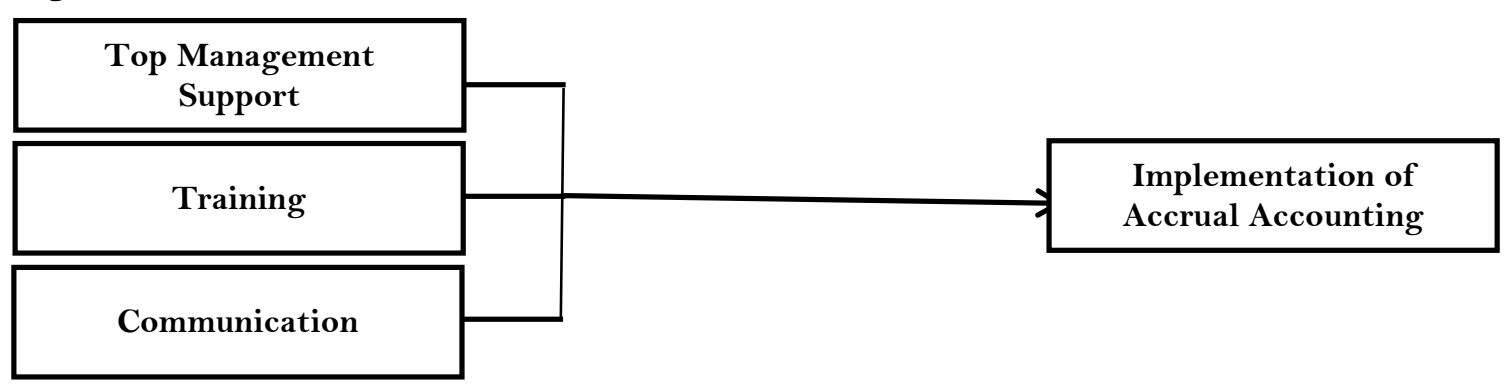

\section{Methodology}

Population refers to all element which is wanted to be investigated to draw the conclusion (Sekaran, 2006). The population in this research was Cianjur District SKPD. there were 65 SKPD such as Regional Secretariat, Regional Inspectorate, DPRD Secretariat, Regional Service, Regional Agency, District and Hospital. The samples were part of the population, consisting of a number of members with characteristics possessed by the population (Sekaran, 2006). (Cooper and Emory, 1996) stated that the population is not limited. Thus, the sample of this research were65 SKPD with a total sample of $65 \times 2=130$ total samples.

The sampling technique was the census sampling method. This method is a technique for determining the overall sample taken from all elements in the population. Thus, it could be used as a sample (Sekaran, 2006). The unit of analysis in this research was the individual who were in charge of preparing financial statement in the Cianjur District SKPD. They were the secretary and accounting department staffs. The determination of the unit of analysis was based on individuals who knew the government regulations on accrual-based accounting.

In the context of this study, the implementation of accrual accounting has been operationalized the application of governmental accounting standard which measured by revenue, expense, asset, liabilities, and equity in the accrual based financial statement, and measure revenue, expenditure, financing in the budgeting based on the financial statement on the accrual accounting (Nasution, 2016). This variable was adopted by Nasution (2016) using 5 dimensions which is revenue recognition, expenses, asset, liabilities, and equaity.

Top management support is the involvement of top managers to make the strategy, providing resources and setting goals. This variable was measured using questions adopted from Aswar and Saidin (2018) modified according to the environment in the Cianjur Regency SKPD. Training is individuals who are in an organization, of course they must have the potential needed by the organization to achieve their goals. According to Noe (2010: 5), Training is a planned effort made by the company to facilitate employee learning based on work competencies carried out. Job competencies which must be possessed include knowledge, skills, or behaviours which are very important for the success of employee performance (Rosyadi \& Mulyani, 2017). This variable was measured using questions adopted from Aswar and Saidin (2018) modified according to the environment in the SKPD Cianjur District.

Communication is disclosure process and understanding the meaning. How great the idea is, it will not be useful if it is not passed on and understood by others. Good communication is very important for the effectiveness of any group or organization. This variable was measured using questions adopted from research (Aswar \& Saidin, 2018).

\section{Result}

Besides, mean and standard deviation were always used to explain research characteristic which used ratio and interval scales. In this research, the interval scale used a five-point Likert scale. Furthermore, suggestions made by 
Muhammad, et al. (2010) regarding the interpretation of average scores were also supported. They recommend that an average score of less than 2.33 was low, scores between 2.33 to 3.67 were considered moderate and values above 3.67 was considered high. The level of statistical significance in this study is $5 \%$. The following results of descriptive statistical analysis of the results of this study are as follows:

Table 1. Result of Descriptive Statistic of Mean and Standard Deviation

\begin{tabular}{lccc}
\hline \multicolumn{1}{c}{ Variable } & Total of Question & Mean & $\begin{array}{c}\text { Std. } \\
\text { Deviation }\end{array}$ \\
\hline Implementation of Accrual Accounting & 5 & 20,18 & 3,009 \\
Top Management Support & 7 & 29,76 & 4,542 \\
Training & 8 & 31,76 & 4,819 \\
Communication & 6 & 25,04 & 4,287
\end{tabular}

Based on descriptive statistic result in table 1, it shows that the biggest mean is in the training which is equal to 31.76 with the number of question items of 7 out of 76 respondents and the standard deviation value of 4,819 . Furthermore, it was followed by the mean value of top management support of 29.76 with a standard deviation of 4.542. Furthermore, the mean value contained in the communication variable is 25.04 with a standard deviation of 4.287. Finally, the mean value for the training variable is 20.18 with a standard deviation of 3.009.

Thus, it can be seen that there is not a large enough gap from the respondent because all the mean and standard deviations of each variable indicate that the standard deviation is smaller than the mean. This shows that the smaller value of the standard deviation, it will describe the level of homogeneity of the data is quite high and shows an average that describes the actual data. In addition, the mean value is also above 20. In this case, the item has a high value which indicates that respondents believed in implementing high accrual accounting to be applied in Cianjur District.

In the result of data processing structural models for path coefficients analysis (Path Coefficients) are obtained as follows:

Table 2. Value of Path Coefficient Analysis

\begin{tabular}{lccccc}
\hline \multirow{1}{*}{ Variable } & Original & Sample & & $\boldsymbol{T}$ & $\boldsymbol{P}$ \\
& Sample $(\mathbf{O})$ & Mean $(\mathbf{M})$ & STDEV & Statistics & Values \\
\hline DTM -> IAA & 0,435 & 0,459 & 0,204 & 2,134 & 0,033 \\
K-> IAA & 0,145 & 0,133 & 0,203 & 0,714 & 0,476 \\
P -> IAA & 0,297 & 0,292 & 0,145 & 2,049 & 0,041 \\
\hline
\end{tabular}

Based on table 2, it can be seen in part of Original Sample $(\mathrm{O})$, it shows the results of the path analysis coefficient values for testing between variables of top management support for the accrual accounting implementation of 0.033 , training for the accrual accounting implementation of 0.476 , communication of the accrual accounting implementation of 0.041 .

Top management support is factor which can improve the implementation of accrual accounting which are the involvement of top managers to start a strategy, provide resources and set goals (Aswar \& Saidin, 2019). Top management support is needed. Thus, the executors of financial statement recording implement the accrual accounting properly.

The result of the research was in line with a research conducted by Aswar and Saidin (2018). It found that there was a positive effect between top management's support for the implementation of accrual-based accounting in Java and Sumatra. In line with research which stated that there was a relation between top management support to the implementation of accrual-based accounting Rosyadi and Mulyani (2017) and also top management support had a positive effect on accrual-based implementation (Safitri, 2017). The results were also in line with the research of Putra and Ariyanto (2015) who conducted research in Badung District. They found that management support had a positive effect on the implementation of accrual accounting.

The results of this research were also in accordance with institutional theory in which the support of top management as a normative pillar. Top management gives responsibility by the imposition of sanctions and rewards so that normative expectations to implementers and motivation to meet these expectations. Thus, it can be considered that if the implementer is supported by the encouragement of top management so the implementer can implement accrual accounting. Thus, the greater the encouragement of top management will increase the implementation of accrual accounting implementation.

This implicated the result because SKPD in Cianjur District, top management support as Policy makers have a very important and vital role because the implementation of accrual accounting is a large project. It requires large resources and also complex changes. The top management support was part of the commitment by the SKPD in Cianjur Regency to adopt and implement accrual accounting. Therefore, it could facilitate the accrual accounting system until the implementation goals are reached. 
Based on the results of data processing, the relation of training to the implementation of accrual accounting showed the value of $\mathrm{t}>$ table of $2.049>1.66123$ and a significant value of $0.041<0.05$ indicated that training had a significant effect on the implementation of accrual accounting.

This finding was consistent with previous research about accounting reformation research. This was because of the findings of Windel and Christiaens (2006) in Flemish, public centres also reported a significant and positive relationship between training and accrual accounting reform. Likewise, the research of Christiaens and Peteghem (2007) empirically proved that the training program had a significant influence on the level of compliance with accounting reform. Consistent with this research, the research of Eriotis et al. (2011) also established a significant and positive relation between training and the rate of adoption of accounting reforms in Greek public hospitals. In Ghana, research conducted by Agyemang (2017) showed that there was a significant positive relationship between training and implementation of AIPSAS.

This research was also in line with what has been conducted in Indonesia. Aswar \& Saidin (2018) found that adequate training had an effect on the implementation of accrual accounting in local governments throughout Java. Kamemy (2017) explained training influences the implementation of accrual accounting in SKPD. In line with research conducted by Kusuma and Fuad (2013), it found that specifically the level of application of accrual accounting was significantly influenced by training of financial staff. Training was a key factor in the successful implementation of accrual accounting because changes which could not be implemented directly without adequate training by each government agency.

This phenomenon could happen because training program had been defined well and effectively. Thus, it increases the intention to use the new system. Defining the right training approach is seen as an important factor which could affect successful implementation because ineffective training methods actually reduce motivation to use the new accounting system.

The results occurred in the Cianjur District SKPD were that the level of accrual accounting adoption could be maximally achieved not only because of qualified employees. There were several factors which supported cities in their regional development and one of them was a training program. Therefore, it could be considered that training was an important factor in increasing the application of accrual accounting. Based on the discussion above, the results showed that an acceptable level of training had been provided to staff appointed by the government. However, controversial training programs was needed because the adoption and implementation of the accrual basis of accounting was a long process project which took years to achieve.

Communication toward implementation of accrual accounting showed value of t-value $>$ t-table of $0.714<1.66123$ and a significant value of $0.476>0.05$ showed that communication significantly influences the implementation of accrual accounting. So it can be concluded, communication does not significantly influence the implementation of accrual accounting.

The results of this study are not in line with research conducted by Putra and Ariyanto (2015) showing that communication, organizational commitment has a positive effect on the readiness of applying accrual-based government accounting standards in Badung Regency. Pratiwi et al, (2017) concluded that communication has a positive effect on accrual accounting in the city government of Bandung.

In the context of Cianjur Regency SKPD broad communication has no effect on the accrual accounting implementation. This was because of the possibility occurred that ineffective communication was built up within the organization. Another possibility, the Cianjur district SKPD organization considered that minimal communication could implement accrual accounting.

\section{Conclusion}

This research aims to examine and find out the effect of top management support, training and communication toward implementation of accrual accounting in Cianjur Regency. Based on the results and discussion after data analysis and testing of the effect of top management, training and communication support on the accrual accounting implementation of 71 respondents in Cianjur Regency. Based on the research findings and discussion, it can be concluded in accordance with the research problem, as follows:

Top management support has a positive and significant effect on the implementation of accrual accounting. This shows that if the implementation is supported by top management, the implementation of accrual accounting will be better. Training affects positively and effectively toward implementation of accrual accounting. This shows that good training will facilitate the implementation of accrual accounting. This result is also due to the implementation of accrual accounting by the government providing facilities and conducting structured training for the implementation phase. Communication has no positive and significant effect on the implementation of accrual accounting. This is because of the possibility that occurs that ineffective communication is built up within the organization.

This research has several limitations in conducting this research. The results of the research only use the research object of Cianjur District in one part of the local government in West Java. Thus, it has not been able to give a more or generalized depiction for the whole related to the implementation of accrual accounting. The research was conducted at the end of the year. Therefore, it coincides with the book closing activities for each regional work unit so that many questionnaires were not returned.

This study contributes to local government especially for SKPD in Cianjur Regency to concern more communication between top and bottom in this organization which means that two ways communication verse versa. Based on the conclusion above, it can be summarized some suggestions for further researchers to add the variables of 
consultant support, education level, and project management support as suggestions for developing research results. Furthermore, the process of compiling and filling out the questionnaire should be simplified, so there is no incomplete in answering questionnaire. Research data collection must be complemented using interview methods to dig deeper into the implementation of accrual accounting. In addition, further research is expected to expand research to not only focus on SKPD in Cianjur District.

\section{References}

Agyemang, J. K. (2017). Factors affecting the implementation of accrual-based international public sector accounting standards (AIPSAS) in Ghana. Texila International Journal of Management, 3(2), 1-12.

Arih, T. N., Rahayu. S \& Nurbaiti, A. (2017). Analisa Faktor-Faktor Yang Mempengaruhi Implementasi Standar Akuntansi Pemerintahan Berbasis Akrual Pada Pemerintah Kota Bandung, Jurnal Manajemen Indonesia, 17(1), 67-78.

Aswar, K., \& Saidin, S. Z. (2018). Accrual accounting adoption in Java Municipalities: An empirical investigation. International Journal of Business and Economic Sciences Applied Research, 11(3), 24-30.

Aswar, K., \& Saidin, S. Z. (2018). The influencing factors on the level of accrual accounting adoption: A conceptual approach. Romanian Economic and Business Review 13 (2), 30-36.

Badan Pemeriksa Keuangan. (BPK) (2018). Indeks Hasil Pemeriksaan Sementara. Diakses O November 2019 https://www.bpk.go.id/ihps/2018/I.

Cavalluzzo, K. S., \& Ittner, C. D. (2004). Implementing performance measurement innovations: Evidence from government. Accounting, Organizations and Society, 29(3-4), 243-267.

Christiaens, J. (2001). Converging new public management reform and diverging accounting practices in Flemish Local Government. Financial Accountability \& Management, 17 (2), 153-170.

Christiaens, J.,\& Peteghaem, V. V (2007). Governmental accounting reform: Evolution of the adoption in Flemish Municipalities. Financial Accountability \& Management, 23 (4), 375-399.

Cohen, S., Keimenaki, E., Zorgios, Y. \& Kaimenakis, N. (2007). An empirical investigation of Greek municipalities accounting practices. Annual conference of the Hellenic Accounting and finance association Patra. 14-15.

Cooper dan Emory, (1996), Metode Penelitian Bisnis, Jakarta: Erlangga.

Eriotis, N. Stamatiadis, F. \& Vasiliou, D. (2012). Assessing accrual accounting reform in Greek Public Hospitals: An Empirical Investigation, International Journal of Economic Sciences and Applied Research, 4(1), 153-183.

Harun, H., \& Kamase, H. P. (2012). Accounting change and institutional capacity : the case of a provincial government in Indonesia. Australasian Accounting Business \& Finance Journal, 6(2), 35-50.

Harun, H., Peursem, K. Van, \& Eggleton, I. (2012). Institutionalization of accrual accounting in the Indonesian public sector. Accounting \& Organizational Change, 8(3), 257-285.

Jantong A, Nurkholis, \& Roekhudin. (2018). Faktor-faktor yang mempengaruhi kesiapan penerapan standar akuntansi pemerintahan berbasis akrual pada pemerintahan daerah, Jurnal Bisnis dan Manajemen. 5(2), 158-169.

Komite Standar Akuntansi Pemerintah. (2015). Standar Akuntansi Pemerintahan, Jakarta

Kristiawati, E. (2015). Faktor-faktor yang mempengaruhi keberhasilan penerapan akuntansi berbasis akrual pada pemerintahan daerah Kalimantan Barat, Akuntabilitas, 8(3), $171-190$

Kusuma, M. I. Y \& Fuad (2013). Analisis faktor-faktor yang mempengaruhi tingkat penerapan akuntansi akrual pada pemerintah, Diponegoro Journal Of Accounting, 2(3), 1-14.

Mcleod, R. H., \& Harun, H. (2014). Public Sector Accounting Reform at Local Government Level in Indonesia. Financial Accountability \& Management, 30(4), 238-258.

Muhammad, N., Maheran, N., Jantan, M., \& Taib, F. (2010). Moderating effect of information processing capacity to investment decision making and environmental scanning. Business Management Quarterly Review, 1(1), 9-22.

Nasution. D, A, D. (2016). Analisis faktor-faktor yang mempengaruhi implementasi SAP berbasis akrual dengan komitmen skpd sebagai variabel moderating pada pemerintah provinsi Sumatera Utara. Jurnal Ekonom, 19(4), 175-185.

Noe, R. A., (2010). Employee Training and Development, 5th edition. New York: McGraw-Hill.

Pratiwi, A. I., Rahayu, S. \& Zutilisna, D. (2017). Teknologi informasi, sumber daya manusia, komitmen dan komunikasi terhadap kesiapan implementasi standar akuntansi pemerintan berbasis akrual pada pemerintah kota bandung (studi kasus: dinas pengelolaan keuangan dan aset daerah kota bandung periode 2015), e-Proceeding of Management, 4(2), 1612 - 1619.

Putra, I. W. G. Y. D. \& Ariyanto, D. (2015). Faktor-faktor yang mempengaruhi penerapan standar akuntansi pemerintahan berbasis akrual. E-Jurnal Akuntansi Universitas Udayana, 13(1), 14-32.

Government Regulation No 24 (2005) Standar Akuntansi Pemerintahan berbasis Kas.

Government Regulation No 71 (2010) tentang Standar Akuntansi Pemerintahan Berbasis Akrual.

Ridder, H., \& Bruns, H. And Spier. F (2006). Managing adoption processes. Public Management Review, 8(1), 87-118.

Rosyadi, M. I \& Mulyani, S. (2017). Analisis faktor-faktor yang mempengaruhi tingkat penerapan akuntansi berbasis akrual di pemerintah kota Bekasi (Studi kasus satuan kerja perangkat kerja pemerintah Kota Bekasi), Profesionalisme Akuntan Menuju Sustainable Business Practice, 491- 503.

Safitri, D. (2017). Faktor faktor yang mempengaruhi penerapan standar akuntansi pemerintahan berbasis akrual (Studi pada skpd pemerintah kabupaten Bengkalis), Jurnal Akuntansi, 5(2), 174-189.

Sekaran, U. (2006). Research Methods forBusiness. A Skill building approach, $4^{\text {th }}$ edition, John Wiley \& Sons.

Scott, W. R. (2008). Institutions and Organizations, Third Edition.

Undang - Undang No 17 (2003) tentang Keuangan Negara, Jakarta.

Undang - Undang No 1 (2004) Perbendaharaan Negara, Jakarta.

Undang - Undang No 15 (2004) Pemerikasaan Pengelolaan dan Tanggungjawab Keuangan Negara, Jakarta.

Widianti, H., Hadiyati, S. N., \& Sulistiyowati, D. (2016). Analisis Faktor-Faktor Yang Mempengaruhi Implementasi Akuntansi Akrual Pada Sektor Pemerintah, SENIT. ISSN 978-602-74355-0-6, 155-162. 
Windels, P., \& Christiaens, J. (2006). Management reform in Flemish public centres for social welfare: examining organisational change. Local Government Studies, 32(4), 389-411.

This is an Open Access article distributed under the terms of the Creative Commons Attribution Licence

(c) (i) 